\title{
Associated Of Coral Reef With Reef Fish In Northern And Southern Gili Air Island And Gili Trawangan Island Lombok
}

\author{
Trisna Wahyu A $\mathrm{P}^{1}$, Helmi Mubarak ${ }^{1}$, Damar Lazuardy Rolian ${ }^{1}$, Hanson Geraldi Pardede ${ }^{1}$, \\ Prabowo ${ }^{1}$, Dhananta Rizka Safitri ${ }^{1}$, Kharisma Zunika Putri ${ }^{1}$, Muhammad Iqbal Kenedi ${ }^{1}$, \\ Ainia Gita Tiara Shanti ${ }^{1}$, Satria Nur Afrizal ${ }^{1}$, Niken Larasayu Santoso ${ }^{1}$, Karina Maharani ${ }^{1}$, \\ Ria Widyaningrum ${ }^{1}$, Azzam Helmi Muflih ${ }^{1}$, Rifki Nur Faizan ${ }^{1}$, Adini Safitri ${ }^{1}$, and Tjahjo \\ Winanto ${ }^{1}$
}

${ }^{1)}$ Marine Science Department, Fisheries and Marine Science Faculty, Jenderal Soedirman University, Indonesia

\begin{abstract}
Damage to coral reef ecosystems is a major problem on the islands of Gili Air and Gili Trawangan. This will have an impact on the presence of reef fish in the area. This study aims to look how much relation caused by associated between live coral cover and reef fish in Gili Air and Gili Trawangan island.. This research method using Line Intersept Transect (LIT), Underwater Visual Census and simple linear regression analysis to know the relation. The percentage of coral cover on Gili Air Island and Gili Trawangan Island on reef flats $(1-5 \mathrm{~m})$ is $11.75 \%$ and $11.67 \%$ respectively, on the reef slopes $(6-10 \mathrm{~m})$ the percentage is $50.4 \%$ and $48.9 \%$. In addition we observed the existence of 11 families reef fish. The abundance of reef fish on Gili Air and Gili Trawangan islands on reefs flat with an average of 0,406 ind $/ \mathrm{m}^{2}$ and 0,137 ind $/ \mathrm{m}^{2}$, on the reef slope on average - respectively 0,434 ind $/ \mathrm{m}^{2}$ and 0,274 ind $/ \mathrm{m}^{2}$. The determinant value in Southern part of both island indicates a value close to +1 and in Northern part of both island indicates a value close to -1 .
\end{abstract}




\section{INTRODUCTION}

Gili Matra is an archipelago made up of three islands, namely Gili Meno, Gili Air and Gili Trawangan located in Lombok, Indonesia. Gili Matra have a great attention of tourists, both domestic and foreign because of coral reefs and mangrove vegetation. as a frequently visited place by tourists, the balance of the ecosystem is an asset of Gili Matra. Status of the Park waters also make travel demand in the region Gili Matra TWP increases. Since declared a conservation area in 1993, tourism activity has grown rapidly, and on the other hand causes the degradation of ecosystems [31]. Coral reefs in the area of Gili Matra is a center of attraction for tourists in the coastal and marine activities, such as snorkeling and diving. Interest in dive increasing since 1995. However, the damage began to occur due to tourist activities that are less cautious.

Coral reefs are a group of individual corals. Light intensity and water quality was good requirements for living coral reefs. Changes in oceanographic conditions can cause the coral susceptible to disease. Corals can be infected to the disease caused by three factors that is the pathogen, genetics, and environmental. Rapid changes in environmental conditions can exacerbate infections because the pathogens are able to reproduce faster [12]. Coral reefs become the habitats of other organism such as sea grass, algae, crustaceans, sponges, mollusks, fish, corals and other biota [9]. The existence of coral reefs that serve as habitat for reef fish has associated with the number of reef fish [26].

According Hallacher [13], reef fish is a group of life fish associated with coral reef ecosystem. Found as many as 113 reef fish families and the most is Perciformes order. The top ten major families of reef fish are Gobiidae, Labridae, Pomacentridae, Apogonidae, Bleniidae, Serranidae, Murraenidae, Syngnathidae, Chaetodontidae, and Lutjanidae.

When viewed in terms of ecology and utilization, reef fish can be grouped into three namely, indicator fish, mayor fish, target fish. Target fish is a group of fish that can be consumed and usually hunted fishermen, indicators fish is a group of fish whose lives have strong associations to the corals and Mayor fish is small fish, 5 to $25 \mathrm{~cm}$ generally [1].

Damage to coral reef ecosystems is a major problem in the tourist park waters of Gili Air and Trawangan. Recorded at 55.39\% condition of conservation area in Gili Indah Lombok is a bad condition [6]. In 2003, amounted to $52.94 \%$ of corals were damaged [4]. Results of research conducted Ahyadi and Jufri [2] showed that until the end of 2008 reached $75 \%$ of coral damage in the area of Lombok Sea Tourist Park. Damage to coral reefs caused the presence of groups reef fish is threatened, and in the case of fishing activities. This study aims to look at how much relation caused by associated between live coral cover and reef fish in Gili Air and Gili Trawangan island.

\section{METHODOLOGY}

This research method is a survey that is research by collecting data directly to the variables that the object of research. This method is also called the research assessment (exploratory), the research is still open and still looking for the elements, characteristics or traits.

\subsection{Time and Place}

The study was conducted on a 1 to 15 August 2017 with a location in the coral reef island of Gili Air and Gili Trawangan, Lombok west. Observations were made on two stations consisting of north and south. Determination of observation stations in the waters of Gili Matra based areas leeward and windward where the area leeward is more sheltered 
southern part by the waves so that the current in the area is quieter, while the area windward is an area that is exposed by the waves so that it has a faster current The sampling was conducted at two different depths are 1-5 meters (reef flat) and 6-10 meters (reef slope). 


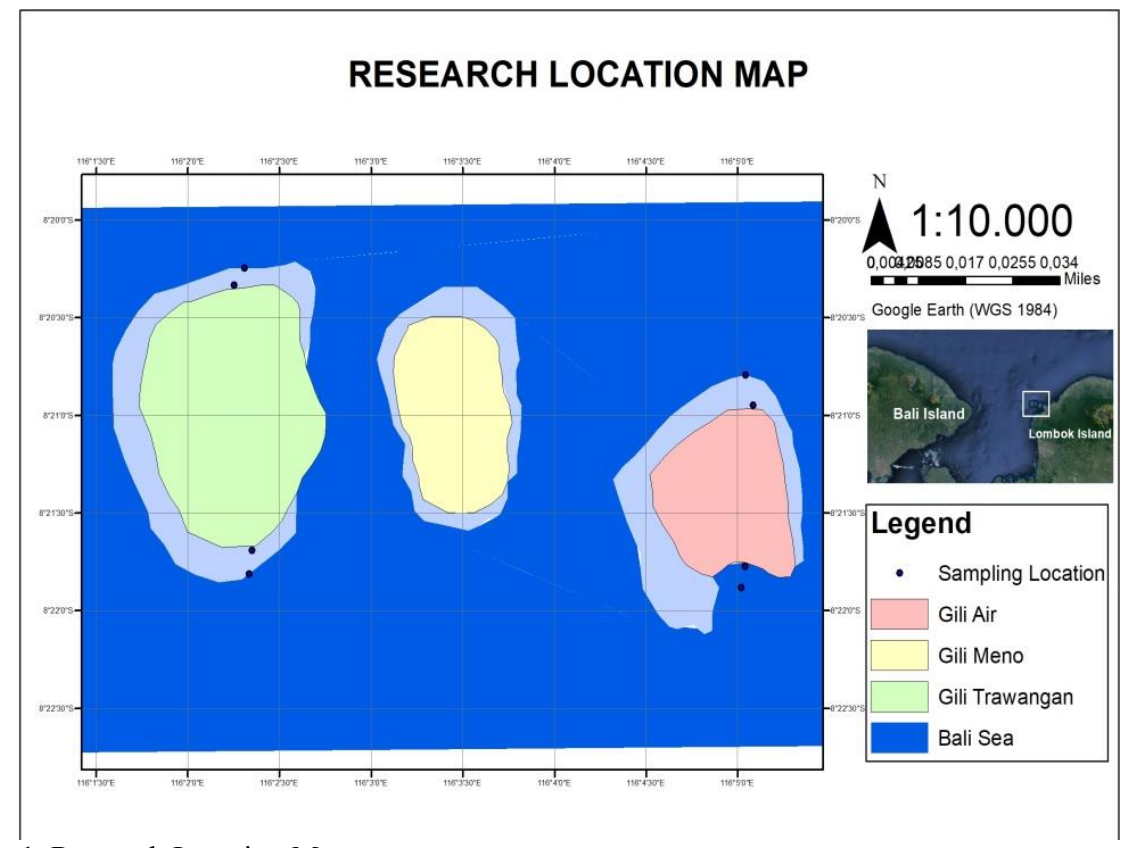

Fig 1. Research Location Map

\subsection{Data Collection}

\subsubsection{Coral Cover}

Determining coral cover, using Line Intercept Transect (LIT) method to see the growth of live reef [11]. Corals observed at a depth of $1-5$ meters using snorkling and a depth of 6-10 meters using SCUBA. Data retrieval begins by placing a roll meter horizontally and drawn parallel to the coastline and drawn along $50 \mathrm{~m}$, then record the shapes of coral growth are only exposed transects on the datasheet.

\subsubsection{Reef Fish}

Reef fish Sampling was done by using Underwater Visual Census following the methods of English et al.[11], that is using belt transects on Line Intercept Transect. The recording was made on a $50 \mathrm{~m}$ transect line while conducting a census of reef fish with the observation distance of $2.5 \mathrm{~m}$ to $2.5 \mathrm{~m}$ to the right and left, so that the observed area measuring $350 \mathrm{~m}(70 \mathrm{~m} \times 5 \mathrm{~m})$. implementation of the UVC in the sea, fish species and number of fish recorded in the data sheet watertight. Fish species have been recorded, then identified using pictorial guide of Setiawan [29] and Allen et al.[3].

\subsubsection{Water Quality}

Measurements were performed insitu. Sampling of water quality consist of temperature, salinity, currnet velocity, $\mathrm{pH}$, brightness. Each measurment, using a different tool. The measurment of temperature is using thermometer tool by dipping the thermometer into the water and wait a few minutes until the mercury stops at a certain temperature. The maesurment of salinity is using refraktometer by putting water on the glass and read the 
scale on refraktometer. The measurment of current velocity is using strap and bottle. The strap and bottle are released and allowed to follow the movement of the mass flow of sea water and write the time and range. The measurment of $\mathrm{pH}$ using Universal $\mathrm{pH}$ by putting litmus paper into water for a few minutes and remove from water then reas the scale. The last measurment that is brightness using secci disk by putting the secchi disk into water until no longer can be seen, at that time write how deep that secchi disk. Then, pull the secchi disk off the water until the secci disk has been seen and write how deep that secchi disk. After that, use the formula to see the brightness. 


\subsection{Data Analysis}

\subsubsection{Percentage Coral Cover}

Calculation coral cover percentage using the formula English et al.,[11], namely:

Description:

$$
N i=\frac{l i}{L} \times 100 \%
$$

$\mathrm{Ni}=$ Percentage of coral cover $(\%)$

li $=$ Total length lifeform living coral

$\mathrm{L}=$ Total length of transects

Status reef coral is divided into 4 categories including $0 \%-24.9 \%$ categorized as poor, $25 \%-49.9 \%$ categorized as moderate, $50 \%-74.9 \%$ categorized as good, and $75 \%-100 \%$ categorized as very good [11].

\subsubsection{Reef Fish Abundance}

The reef fish abundance is expressed by a number of individuals per area using Odum's formula [26], namely:

Description:

$$
X i=\frac{n i}{A}
$$

$\mathrm{Xi}=$ abundance of individuals (ind $/ \mathrm{m} 2$ )

$\mathrm{ni}=$ number of fish species to $-\mathrm{i}$

$A=$ area transect $(\mathrm{m} 2)$

\subsubsection{Analysis the Relation Between Percentage Coral Cover With Abundance Of Reef Fish}

Analysis used to see the effect of the percentage of coral cover and abundance of reef fish that is simple linear regression analysis, where the independent variable $(\mathrm{X})$ is the percentage of coral cover and the dependent variable (Y) is the abundance reef fish. Sarwono [29] explains, the value of coefficient $\left(R^{2}\right)$ is used to examine the relationship between variables. The coefficient value close to -1 has a weak influence between the two variables or not at all, while a value close to +1 coefficient has a positive influence.

\section{RESULTS AND DISCUSSION}

\subsection{The Percentage Of Coral Cover}

Results obtained from the research that has been done using method Line Intercept Transect the percentage of coral cover located on the island of Gili Air and Trawangan can be seen in Figure 2. 


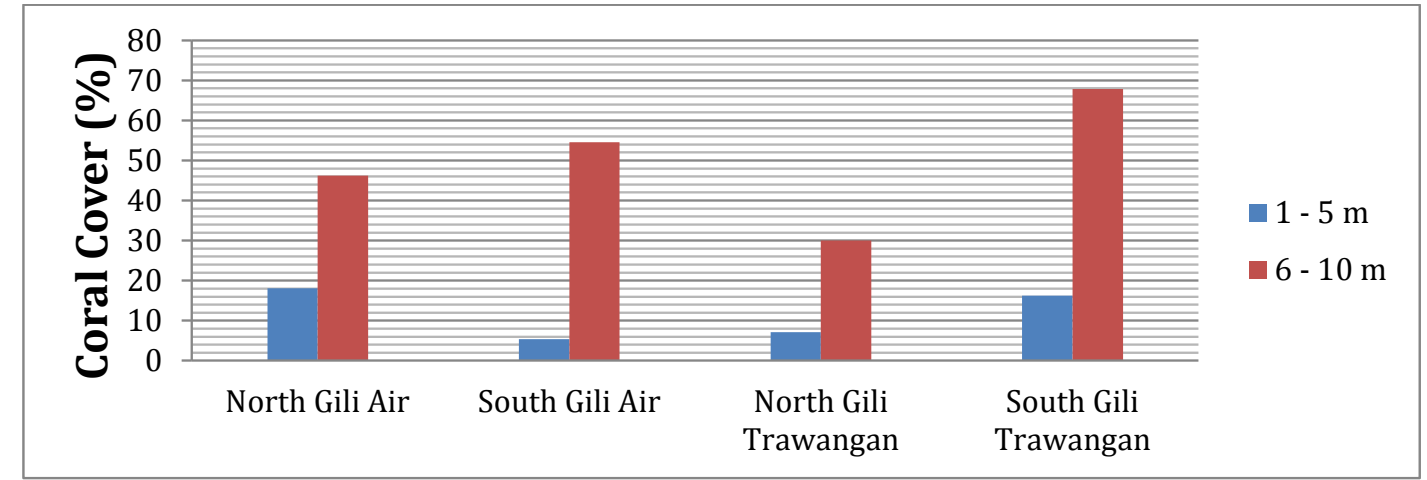

Fig 2. Graph of the percentage of coral cover 
The result show, on a reef flat area $(1-5 \mathrm{~m})$, the highest percentage was found in the northern part of Gili Air (18.1\%), while the lowest percentage was found in the southern part of Gili Air $(5,4 \%)$. The highest percentage on reef slope area $(6-10 \mathrm{~m})$ obtained in the southern part of Gili Trawangan $(67.8 \%)$, while the lowest percentage was found in the northern part of Gili Trawangan (30\%).

Based on data from the graph as a whole, the southern part of the island has the higher percentage than the northern part of the islands, If the terms of the depth, at a depth of 1-5 m has lower percentage or can be categorized as bad condition compared to a depth of $6-10 \mathrm{~m}$ which can be categorized as good condition. The low percentage of coral cover at a depth of 1-5 m impact from the number of anthropogenic activities so much coral damaged by trampled by tourists who lacked knowledge about the importance of the reef environment. the percentage of live coral cover is affected by natural interactions found in the waters surrounding ecosystems and human activity. Gili Air Island and Gili Trawangan Islands Tourism Region is a place where many visitors ecotourism activities that directly or indirectly affect coral reef ecosystems. Various studies showed to us that, coral decline may be facilitated or accompanied by a detrimental increase in algal turf biomass [7, 10, 17, 23, 34]. Cernohorsky et al., [8] said that small herbivorous fishes can play an important role in preventing the accumulation of algal biomass on coral reefs.

\subsection{The Abundance Of Reef Fish}

The results calculation of reef fish abundance in this research has been done by using Underwater Visual Census can be seen in Figure 3.

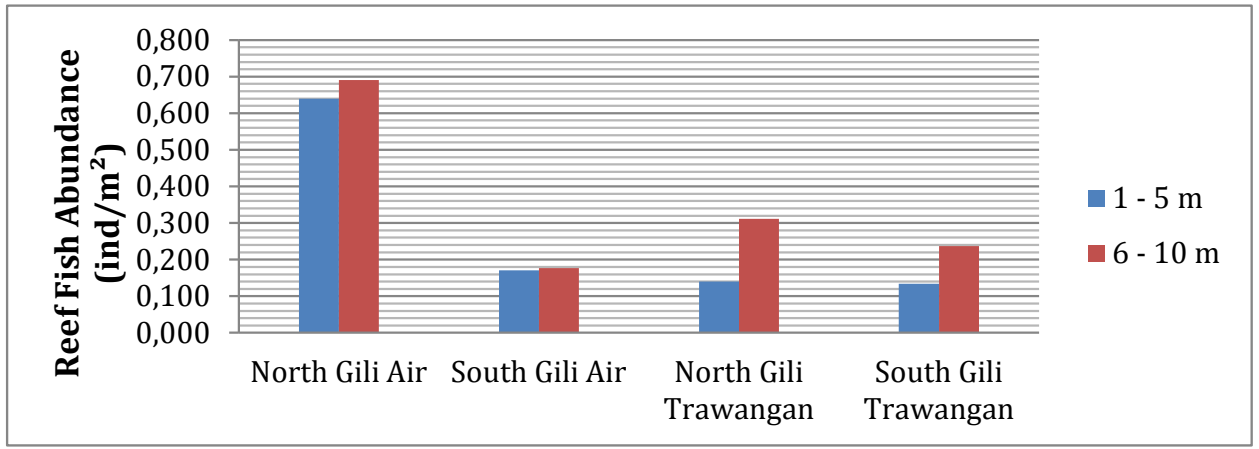

Fig 3. Graph of the reef fish abundance

The results show, on reef slope area $(6-10 \mathrm{~m})$, the highest fish abundance was found in the northern part of Gili water $\left(0.691\right.$ ind $\left./ \mathrm{m}^{2}\right)$, while the lowest abundance of fish found in the Southern part of Gili Air $\left(0.177 \mathrm{ind} / \mathrm{m}^{2}\right)$. The highest fish abundance on reef flat area $(1-5 \mathrm{~m})$ was found in the northern part of Gili Air $\left(0.640 \mathrm{ind} / \mathrm{m}^{2}\right)$, while the lowest percentage was found in the southern part of Gili Trawangan $\left(0.134 \mathrm{ind} / \mathrm{m}^{2}\right)$.

According to the criteria [35], the category of an abundance of reef fish including "slightly" if the transect density less than 0,2 ind / $\mathrm{m} 2$; including "a lot" if the density is between 0.2 to

0.4 ind / $\mathrm{m} 2$; and including the "abundant" if the density over than 0,4 ind $/ \mathrm{m} 2$. Based on these criteria, the Northern part of Gili Air was categorized abundant while 3 other side was categorized slightly

Our study showed evidence that Northern part of Gili Air can be effective for conservation of commercially important coral reef fishes, even in the face of high tourist and fishing activity pressure. For example, higher densities of the three most abundant commercially important coral reef fish families or subfamilies (Acanthuridae, Pomacentridae, and Chaetodontidae) were recorded in Northern part of Gili Air Island. The overall, bad condition of reef fish abundance is in 3 location that is southern part of both islan an northen part of Gili Trawangan Island. Some research has showed that reef fish behavior can be affected by the presence of perceived threats, including fishing activities [18]. Fishes, for example, may stay inside or close to corals most of the time if the fish senses existence of people activities.

The existence of reef fish greatly influenced by factors both physical and chemical oceanography. Water conditions were not good to encourage fish to migrate to another, causing the abundance that is in place can be a little. The existence of coral reefs make the ecosystem in the area is stable, so there is no imbalance between extinction and speciation. Based on the overall chart data at two depths, the northern part of the island of Gili Air and Gili Trawangan has a higher abundance of fish from the southern part of the islands. This is due, in the northern 
area of the islands have coral cover is low so that the abundance is high but the diversityis a bit, and and vice versa in the southern part of both islands have high coral cover so the abundance tends to be small but high diversity.

Table 1. Reef fish Species found at Gili Trawangan Island and Gili Air Island

\begin{tabular}{|c|c|c|c|c|c|c|c|c|}
\hline \multirow{3}{*}{ Species } & \multicolumn{4}{|c|}{ Gili Trawangan } & \multicolumn{4}{|c|}{ Gili Air } \\
\hline & \multicolumn{2}{|c|}{$\begin{array}{l}1-5 \mathrm{~m} \\
\text { (Depth) }\end{array}$} & \multicolumn{2}{|c|}{$\begin{array}{l}6-10 \mathrm{~m} \\
\text { (Depth) }\end{array}$} & \multicolumn{2}{|c|}{$\begin{array}{l}1-5 \mathrm{~m} \\
\text { (Depth) }\end{array}$} & \multicolumn{2}{|c|}{$6-10 \mathrm{~m}$ (Depth) } \\
\hline & $\begin{array}{l}\text { North } \\
\text { ern }\end{array}$ & $\begin{array}{c}\text { South } \\
\text { ern }\end{array}$ & $\begin{array}{l}\text { North } \\
\text { ern }\end{array}$ & $\begin{array}{c}\text { South } \\
\text { ern }\end{array}$ & $\begin{array}{l}\text { North } \\
\text { ern }\end{array}$ & $\begin{array}{c}\text { South } \\
\text { ern }\end{array}$ & Northern & Southern \\
\hline $\begin{array}{l}\text { Abudefduf } \\
\text { bangalensis }\end{array}$ & & & & & & & 11 & \\
\hline $\begin{array}{l}\text { Abudefduf } \\
\text { septemfasciatus }\end{array}$ & 5 & & & & & & & \\
\hline $\begin{array}{l}\text { Abudefduf } \\
\text { sexcafiatus }\end{array}$ & 2 & & & & 35 & 10 & & \\
\hline Abudefduf vaigiensis & & & & & 20 & & & \\
\hline $\begin{array}{l}\text { Acanthurus } \\
\text { auranticavus }\end{array}$ & 2 & & & & & & & \\
\hline $\begin{array}{l}\text { Acanthurus blochii } \\
\text { Acanthurus }\end{array}$ & & & & & 11 & & 60 & \\
\hline japonicus & & & 2 & & & & & \\
\hline $\begin{array}{l}\text { Acanthurus } \\
\text { leucopareius }\end{array}$ & & & & & & & & 4 \\
\hline $\begin{array}{l}\text { Acanthurus } \\
\text { leucosternon }\end{array}$ & & & 1 & & & & & \\
\hline Acanthurus lineatus & 5 & & & & 11 & & 11 & \\
\hline $\begin{array}{l}\text { Acanthurus } \\
\text { triostegus }\end{array}$ & 3 & & & & & & 7 & \\
\hline Acanthurus tristis & & & 10 & & & 1 & & \\
\hline Acanthurus blochii & & & & & & 15 & & \\
\hline $\begin{array}{l}\text { Acanthurus } \\
\text { leucocheilus }\end{array}$ & & & 5 & & & & 3 & 1 \\
\hline Achanthurus nigroris & & & 4 & & & & & \\
\hline $\begin{array}{l}\text { Amblyglyphidodon } \\
\text { aureus }\end{array}$ & & & & 3 & & & & \\
\hline $\begin{array}{l}\text { Amphiprion } \\
\text { sandaracinos }\end{array}$ & & & & 2 & 3 & & & \\
\hline Balistapus undulatus & & & & & & & 5 & \\
\hline Chaetodon collare & & & & & 4 & & & \\
\hline Chaetodon selene & & & & & & & 1 & \\
\hline Chaetodon speculum & & & & 4 & & & & \\
\hline $\begin{array}{l}\text { Chaetodon } \\
\text { triangulum }\end{array}$ & & & & & & & 3 & \\
\hline $\begin{array}{l}\text { Chaetodon } \\
\text { Tricinctus }\end{array}$ & & & & & & & 1 & \\
\hline $\begin{array}{l}\text { Chaetodon } \\
\text { vagabundus }\end{array}$ & 5 & & & & 9 & & & \\
\hline Cheilinus trilobatus & & & & & & & 3 & \\
\hline
\end{tabular}


Cheilodipterus artus

Cheilodipterus

isostigmus

5

Chlorurus bleekeri

Chlorurus

microrhinos

8

Chlorurus troschelii

11

Chromis

atripectoralis

Chromis caudalis

10

13

Chromis dimidiata

Chromis iomelas

2

Chromis margaritifer 15

10

Chromis morgantilei

5

Chromis xanthura

Chrysiptera Kuiteri

Chrysiptera taupou

Cryptosentrus sp

18

20

Ctenochaetus

cyanocheilus

Ctenochaetus

striatus

Fistularia

commersoni

Halichoeres

hotulanus

Hemiglyphidodon

plagiometopon

Heniochus

diphreutes

Heniochus various

Labroides bicolor

Lutjanus kasmira

Melichthys indicus

Neoglyphidodon

crossi

Neoglyphidodon

oxyodon

Neoniphon

aurolineatus

Neopomacentrus

violascens

3

1

10

5

4

3

2

47

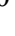

Ostracion meleagris

Parapercis

hexophtalma

Pomacentrus

auriventris

Pomacentrus

cuneattus

1

1

1 
Pomacentrus

moluccensis

Pomacentrus similis

Premnas blaculeatus

Pygoplites

diacanthus

Scarus niger

Scarus rivulatus

Scoloposis

billeniatus

Siganus virgatus

Siganus vulpinus

Zanclus cornutus

Zebrasoma

rostratum
10

5

1

2

5

1

6

1

1

12

$2 \quad 10 \quad 6$

A total of 69 fish species were identified within this study (Table 1). Family of fish that are found on the island of Gili Air, there are Pomacentridae, Chaetodontidae, and Scaridae, but some families was founded but not many.. There are Lutjanidae, Acanthuridae, Gobiidae, Zanclidae, Nemipteridae, Fistulariidae, Apogonidae, and Balistidae. Gili Trawangan island also has many family of fish are found such as Acanthuridae and Pomacentridae, but some families was founded but not many. There are Zanclidae, Ostraciidae, Fistulariidae, Apogonidae, Scaridae, and Balistidae. almost all of which can be found is herbivore fish. In addition, many of the species, especially those with comparatively overall low densities, were found in both location. The distribution of reef fish are highly restricted with oceanography condition and living coral [21, 19, 24].

Other factors such as destructive fishing methods is a negative factor for the resilience process coral. On the contrary, the positive factors that are used as protection and conservation are community policies and initiatives [25, 31]. As reported by Suana and Ahyadi, [32], the use of ecosystems in Gili Matra is as a tourist attraction of the sea and fisheries activities that affect each other on coral reef ecosystems. In recent decades, diving and fishing activities have been increasing since 1993. The complexity in resource management in Gili Matra has led to a variety of environmental problems. Various studies have also demonstrated that Acanthuridae predominated in the shallow reef habitats $(<5 \mathrm{~m}$ depth) [20], In this case, maybe the Northern part of Gili Air provide a good algal turf food source and has a better oceanography condition. Most relatively undisturbed reefs support a high biomass of herbivorous fish, but a low biomass of their algal turf food source: it is the high productivity of algal turfs rather than their standing crop that maintains a high standing stock of grazers $[14-16,22,28)$.

\subsection{Percentage Coral Cover Relationship With Reef Fish Abundance}

The Calculation results using simple linear regression equation be obtained in the northern part of both island, namely: $y=0,4133 x+0.0694$ with determinant value $\left(R^{2}\right) 0,425$, while in the southern part of both island, namely: $y=5,919 x-0.06091$ with a value determinant $\left(R^{2}\right) 0.5909$. The difference value of the determinant indicated differences oceanographic characteristics that may affect the ecosystem in the region. Determinant value indicates a value close to +1 in both parts of the island which means there is a strong relationship between the percentage of coral cover with an abundance of reef fish. Instead of determinant value indicates a value close to -1 which means there is a weak relationship between the percentage of coral cover with an abundance of reef fish. 


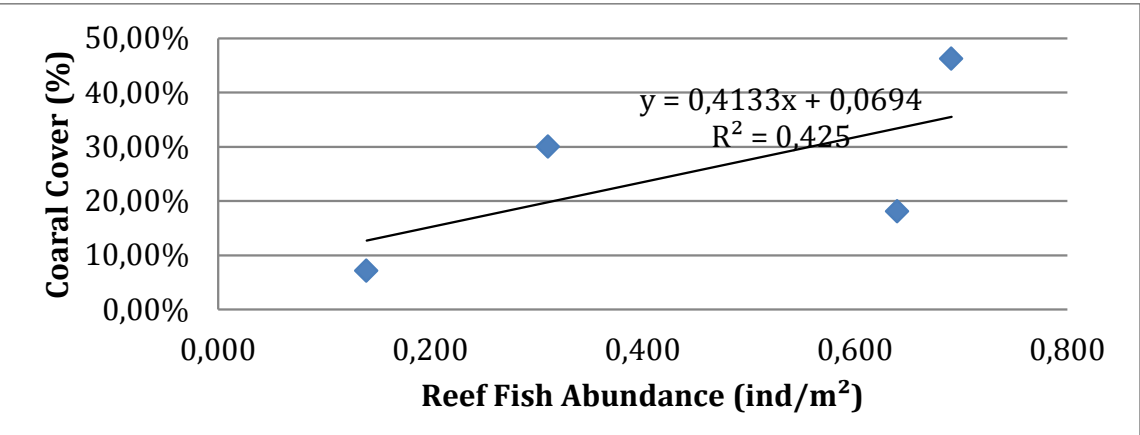

Fig 4. Graph the relationship of coral cover with abundance of coral reef fish on Gili Air and Gili Trawangan northern part

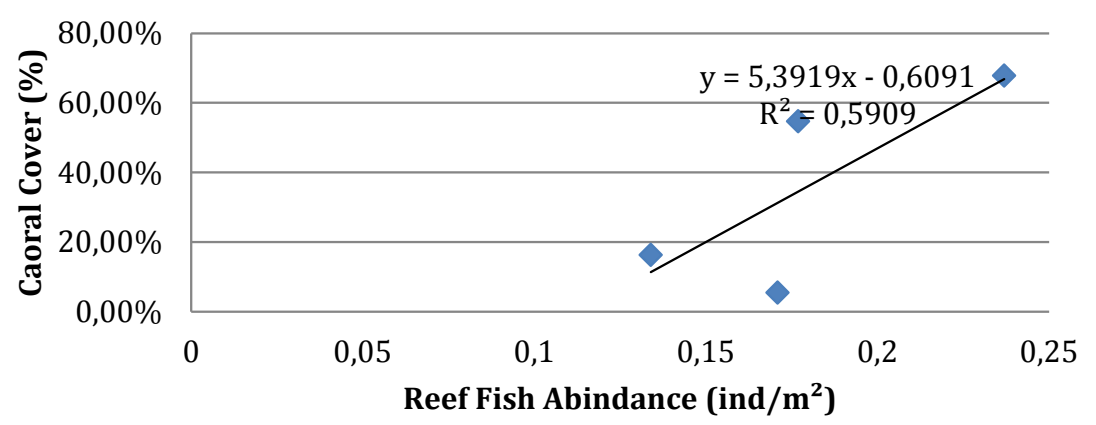

Fig 5. Graph the relationship of coral cover with abundance of coral reef fish on Gili Air and Gili Trawangan southern part

Based on the research that has been done, the chart above shows, the greater the percentage of coral cover is found then the there is great abundance of coral reef areas. The magnitude of the percentage influenced by several factors such as natural interactions found in the waters surrounding ecosystem, the human activity and the physical parameters of the water chemistry that research shows the results or the value that is optimal for the growth and development of coral reefs.

\subsection{Water Quality}

The Result of measurment from the field, water current velocity was greatest in the leeward site (South) on both island, probably due to strong tidal currents. But there was different current velocity in the windward site (North). This study was done coinciding with the eastern monsoon. The consequently is in Asia the air pressure is low and in Australia the air pressure is high. it makes the wind blow from Australia to Asia. the wind that blows brings a lot of effects for what it passes like currents, waves and tides. Differences in wind direction also affect the difference in current velocity in coastal areas. Water flow and turbulence determine the rate of nutrient supply to algae and are major drivers of productivity [35].

Table 2. Water Quality Data

\begin{tabular}{|ccccccc|}
\hline No. & Location & $\begin{array}{c}\text { Temperature } \\
\left({ }^{\circ} \mathrm{C}\right)\end{array}$ & $\begin{array}{c}\text { Salinity } \\
(\mathrm{ppt})\end{array}$ & $\mathrm{pH}$ & $\begin{array}{c}\text { Brightness } \\
(\text { meters })\end{array}$ & $\begin{array}{c}\text { Current } \\
\text { velocity } \\
(\mathrm{m} / \mathrm{s})\end{array}$ \\
\hline 1 & North Gili Air & 25 & 32 & 7 & 5 & 0,19 \\
2 & South Gili Air & 25.8 & 32 & 8 & 5 & 0,23 \\
3 & North Gili Trawangan & 26.4 & 33 & 7 & 5 & 0,15 \\
4 & South Gili Trawangan & 27 & 32 & 8 & 5 & 0,2 \\
\hline
\end{tabular}

Based on the measurement water quality that, on the whole is still in a tolerant condition of marine ecosystem. Good environmental conditions can make the growth of corals and biota association grow well. Value of the sea water quality standard for marine life which is set by the Environment Decree No. 51 year 2004 that is 33-34 ppt, 
and according Dahuri et al. [9], generally at a salinity of 30-35 ppt salinity is good for coral reefs to grow. According to Anwar et al. [4] explains that a good temperature range for fish is $25^{\circ} \mathrm{C}-32{ }^{\circ} \mathrm{C}$. The pH values obtained are included in the ideal category for the life of the organism as an ideal category generally has a $\mathrm{pH}$ between 7 to 8.5 .

\section{CONCLUSION}

Based on the results of this study concluded that the percentage of coral cover at the reef flat was categorized as poor and at reef slope was categorized as good. The North side of Gili Air was categorized abundant, however 3 other side was categorized slightly. There are a strong relationship between the percentage of coral cover with an abundance of reef fish in the southern part of both island and weak relationship in the norhtern part. It means the higher value percentage of coral cover can found, the higher abundance of reef fish in that areas.

The authors would like to thank to National Water Conservation Area Centers (BKKPN) Archipelago of Gili Matra for the facility as well and Marine Science Department from Soedirman University. The author also thankful to Scientific Communication In Fisheries And Marine Sciences (SCIFIMAS) 2018 that give the opportunities to publish the manuscript.

\section{REFERENCES}

1. M. Adrim, M Hutomo. Netherlands J. Sea Res. 23, 85-93. (1989)

2. H. Ahyadi, A. Jufri, Report of Research and Development. Regional Development Planning Agency, West Nusa Tenggara, Mataram. 121p. (2008)

3. G. R. Allen, Steene, P. Human, and N. DeLoach. Reef Fish Identification. Tropical Pacific. Florida. (New World Publications, Inc. 484p, 2007)

4. J. Anwar, A. J. Whitten, S. J. Damanik, N. Hisyam. Ecosystem Ecology of Sumatra.Yogyakarta: Gadjah Mada University Press. 653 p. (1984)

5. I. Bakhtiar. Jur Bio Tro. 5, 1-9 (2004)

6. I. Bakhtiar, T. Karnan, A. Hidayat, Arianto, E. Bursan, and Susiono. Activity reports Development and Conservation Business Improvement Area in Persons and Natural Resources Conservation Konservasi.Unit, West Nusa Tenggara, Mataram. 20p. (2000)

7. C.L. Birrell, L.J. McCook, B.L. Willis. Mar. Pollut. Bull. 51, 408-414. (2005)

8. N.H. Cernohorsky, T.R. McClanahan, I. Babu, M. Horsák. Ind. Ocean. Coral Reefs. 34,1023 - 1035 (2015)

9. R. Dahuri, J Rais., S. P. Ginting, M.J. Sitepu. Management of Coastal and Marine Resources Integrated. PT. Pradnya Paramita. 305p. (2008).

10. G. Diaz-Pulido, L.J. McCook. Coral Reefs. 23, 225-233 (2004)

11. S. English, C. Wilkinson, V. Baker. Survey Manual For Tropical Marine Resources. (Townsville: Autralian Institute of Marine Science, 390p, 1997)

12. Estradivari. The Reefs Jakarta Report: Long-term observations. (Indonesia, Jakarta, p: 134-135. 2007)

13. L. E. Hallacher, The Ecology of Coral Reef Fishes.http://www.kmec.uhh.hawaii.edu/Quest Info/Coral20Reef 20 Fishes20-20May 202003. pdf. Access 27 September 2017. (2003)

14. B.G. Hatcher. Trends Ecol. Evol . 3, 106-111 (1988)

15. B.G. Hatcher. Trends Ecol. Evol. 5, 149-155 (1990)

16. B.G. Hatcher, A.W.D. Larkum. J. Exp. Mar. Biol. Ecol. 69, 61-84 (1983)

17. T.P. Hughes, M.J. Rodrigues, D.R. Bellwood, D. Ceccarelli, O. Hoegh-Guldberg, L. McCook, N., Pratchett, M.S. Moltschaniwskyj, R.S. Steneck, B. Willis. Curr. Biol. 17, 360-365. (2007)

18. F.A. Januchowski-Hartley, N.A. Graham, D.A. Feary, T. Morove, J.E. Cinner. PLoS One 6, e22761 (2011) 
19. M.N. Lavides, N.V. Polunin, S.M. Stead, D.G. Tabaranza, M.T. Comeros, J.R. Dongallo. Environ. Conserv. 36, 235-244 (2009)

20. M. S. Lewis. J. Exp. Mar. Biol. Ecol,. 81, 215-228 (1985)

21. S. Mamauag, P. Aliño, R. Gonzales, M. Deocadez. Philipp. Agric. Sci. 92, 370-387 (2009)

22. L.J. McCook. Coral Reefs. 18, 357-367 (1999)

23. J.W. McManus, J.F. Polsenberg. Prog. Oceanogr. 60, 263-279 (2004)

24. C.L. Nañola Jr, P.M. Aliño, K.E. Carpenter. Environ. Biol. Fishes 90, 405-420 (2011)

25. D. Obura, and G. Grimsditch. Resilience Assessment of Coral Reefs Rapid assessment protocol for coral reefs, focusing on coral bleaching and thermal stress (p. 71). (IUCNResilienceScience Group Working Paper Series - No 5, Gland, Switzerland. 2009)

26. E. P. Odum. Fundamentals of Ecology. (W.B. Sounders Company, Ltd. Philadelphia, 1971)

27. A. B. Rondonuwu, J. L. Tombokan, and U. N. W. J. Rembet. Jur Ilm Pla. 1, 87 - 92 (2013)

28. G.R. Russ. Coral Reef. 22, 63-6. (2003)

29. J. Sarwono. Quantitative and Qualitative Research Methods. (Yogyakarta, Science Graha 286 p, 2006)

30. F. Setiawan. Identification Field Guide Reef Fish and Marine Invertebrates. ( Manado 350 p, 2010)

31. B. Steneck. How to kill a coral reef: Lessons from the Caribbean. http://www.reefresilience. org/ Toolkit Coral/C3a1_Herbivory.html. Access 29 April 2018. (2012).

32. I. W. Suana, H. Ahyadi. Jour of Coas Dev. 16, 94-101 (2012)

33. R. Sukarno, N. Aziz, Darsono, K. Moosa, M. Hutomo, Martosewojo., and Romimohtarto. Sumber Daya, Permasalahan dan Pengelolaannya. (Proyek Penelitian Potensi Sumber Daya Alam Indonesia, 109 p, 2003)

34. M.J.A. Vermeij, I. van Moorselaar, S. Engelhard, C. Hörnlein, S.M. Vonk, P.M. Visser, R.K.F. PLoS One 5, $1547-1551(2010)$

35. S.L. Williams, R.C. Carpenter. J. Exp. Mar. Biol. Ecol. 226, 293-316 (1998) 